\title{
OJOS DE GATO
}

Por la voluntad de la naturaleza es que estoy buscando es que estoy huyendo ¿ la cobardía está adelante? los rostros en su simetría de gestos tus párpados que traen lluvia: un soplo de iris,

la pestaña del aguacil que vibra:

toda la oscuridad llena de oro quisiera ser libre

libre

de mi propia libertad!

es que estoy buscando

es que estoy huyendo.

Tengo el poderoso perfil

de los vientos en sombra

en el ángulo recto

que tiembla

en posición fetal.

No se ha librado la sombra

el Mercader se aleja

y mi alma con todo el oro

de su cruz

sangra

sangra

en los cuatro puntos cardinales

es que estoy huyendo...

y la felicidad viene detrás

con toda su oscuridad llena de oro. 
SIN TÍTULO

Toma la sangre

del templo

como sangra el pecho

de estalactitas.

Toma la sangre

de mi pecho

cómo sangra la sangre

de tus labios

cómo besa tu sangre

de sangre.

Toma el puñal afílalo en los dientes

apuñala el sueño

que gangrena...

apuñala un sí

apunala un no

vida o muerte

sangre a sangre

sangre y sangre

sangre sin sangre

no! 